\title{
PERSEPSI MASYARAKAT TERHADAP PEMBANGUNAN PEMBANGKIT LISTRIK TENAGA PANAS BUMI (PLTP) DI KECAMATAN PAUH DUO KABUPATEN SOLOK SELATAN
}

\author{
Taufik Iqbal, Hasbullah Malau \\ Fakultas Ilmu Sosial Universitas Negeri Padang \\ taufikiqbal252@gmail.com
}

\begin{abstract}
The background of this research is the development of a Geothermal Power Plant (PLTP) in the District of Pauh Duo, where renewable energy is needed as an alternative to replacing fossil energy which is dwindling. However, the development of this PLTP certainly has an impact on the community around the construction site, both the impacts that are felt socially, economically, and environmentally. Resulting in various perceptions among the people. This study aims to determine how people's perceptions of the development of the Geothermal Power Plant (PLTP) in the District of Pauh Duo, South Solok Regency. This research is a type of descriptive research that uses a quantitative approach. The population of this research is the community of Pauh duo sub-district. Researchers use cluster sampling techniques in determining the sample. The samples in this study were 99 people. Data collection techniques used in this study were questionnaires as primary data collection techniques, in the form of questionnaires to the public. As well as documentation as a secondary data collection technique. Then the data is processed using the SPSS application. Based on the results of the questionnaire that was distributed to the community, the results of the community's perception of the development of the Geothermal Power Plant (PLTP) were seen from the social aspect having a fairly good perception index with a percentage of 56.89 percent. Viewed from the economic aspect it has a fairly good perception index with a percentage of 60.35 percent. Viewed from the aspect of the environment it has a good perception index with a percentage of 76.29 percent.
\end{abstract}

Keywords: Perception, Social aspects, Economic aspects, Environmental aspects.

\begin{abstract}
Abstrak
Latar belakang penelitian ini adalah pembangunan Pembangkit Listrik Tenaga Panas Bumi (PLTP) di Kecamatan Pauh Duo, dimana energi terbarukan dibutuhkan sebagai alternatif untuk pengganti energi fosil yang jumlahnya semakin berkurang. Namun pembangunan PLTP ini tentu mempunyai dampak terhadap masyarakat yang berada di sekitar lokasi pembangunan, baik itu dampak yang dirasakan secara sosial, ekonomi, maupun lingkungan. Sehingga menyebabkan timbulnya berbagai persepsi dikalangan masyarakat. Penelitian ini bertujuan untuk mengetahui bagaimana persepsi masyarakat terhadap pembangunan Pembangkit Listrik Tenaga Panas Bumi (PLTP) di Kecamatan Pauh Duo Kabupaten Solok Selatan. Penelitian ini adalah jenis penelitian deskriptif yang menggunakan pendekatan kuantitatif. Populasi penelitian ini adalah masyarakat kecamatan pauh duo. Peneliti menggunakan teknik cluster sampling dalam menentukan sampel. sampel dalam penelitian ini adalah sebanyak 99 orang. Teknik pengumpulan data yang digunakan dalam penelitian ini adalah kuesioner sebagai teknik pengumpulan data primer, berupa pembagian angket kepada masyarakat. Serta dokumentasi sebagi teknik pengumpulan data sekundernya. Kemudian data diolah menggunakan aplikasi SPSS. Berdasarkan hasil kuesioner yang telah dibagikan kepada masyarakat, diperoleh hasil persepsi masyarakat terhadap pembangunan Pembangkit Listrik Tenaga Panas Bumi (PLTP) dilihat dari aspek sosial memiliki indeks persepsi cukup baik dengan persentase sebesar 56,89 persen. Dilihat
\end{abstract}


dari aspek ekonomi memiliki indeks persepsi cukup baik dengan persentase 60,35 persen. Dilihat dari aspek lingkungan memiliki indeks persepsi baik dengan persentase sebesar 76,29 persen.

Kata Kunci: Persepsi, Aspek sosial, Aspek ekonomi, Aspek lingkungan.

\section{PENDAHULUAN}

Keperluan energi esensial dunia diprediksi akan melonjak lumayan tinggi sejalan dengan pertambahan populasi dan kemajuan ekonomi dunia. Energi fosil masih menjadi andalan utama dalam memenuhi kebutuhan energi dunia, di tahun 2011 keperluan atas energi fosil diketahui sebanyak 10.668 juta TOE atau $82 \%$ dari total keperluan energi, dan melonjak menjadi sebesar 14.898 juta TOE pada tahun 2035. Pada rentang waktu tahun 2011 sampai dengan tahun 2035, keperluan terhadap batu bara mengalami kenaikan terbesar dibandingkan dengan bahan bakar fosil lainnya dan sejak tahun 2020 akan menggantikan peran minyak bumi (Outlook Energi Indonesia 2014).

Indonesia sebagai salah satu negara dengan laju perkembangan populasi penduduk dan geliat ekonomi yang sedang gencar-gencarnya dicanangkan oleh pemerintah, sehingga memerlukan sumber energi yang besar. Sekarang penggunaan energi di indonesia masih dimonopoli oleh konsumsi bahan bakar fosil. Terlebih, sekarang pemanfaatan energi fosil ini mengantongi 94\% dari jumlah pemakaian energi nasional (Okefinance).

Kebutuhan energi vital dunia diprediksi akan melambung lumayan tinggi bertepatan dengan pertambahan populasi dan kemajuan ekonomi dunia. Energi fosil masih menjadi andalan utama dalam memenuhi kebutuhan energi dunia, Dampak dari aspek ekonomi masyarakat yang berada disekitar daerah pembangunan PLTP ini mendapatkan ganti rugi terhadap lahan yang terpakai oleh PT suprame Energy Muara Laboh. Dengan adanya ganti rugi lahan, masyarakat bisa membeli lahan pertanian di tempat lain, membangun rumah, dan lain sebagainya. Dampak dari aspek sosial pembangunan PLTP ini bisa menimbulkan kecemburuan sosial antar masyrakat yang berada disekitar lokasi pembangunan PLTP. Kondisi ini terjadi lantaran tidak semua penduduk yang berdiam di sekitar area pembangunan itu merupakan pemilik lahan yang di gunakan. Akan tetapi masyarakat yang berada disekitar lokasi tersbut secara tidak langsung menerima dampak yang sama dari pembangunan tersebut. Dari aspek lingkungan banyak sekali aspek negatif dari pembangunan PLTP ini, seperti berpengaruh kepada kebugaran penduduk lantaran pergantian mutu lingkungan menjadi buruk karena kegiatan saat konstruksi penggalian sumur pabrikasi, injeksi, uji sumber perakitan dan pada tahapan operasi sumber tersebut. 
Melihat dampak yang timbul akibat adanya pembangunan PLTP tersebut. Maka menimbulkan berbagai persepsi di kalangan masyarakat. Persepsi pada prinsipnya menggambarkan opini seseorang tentang suatu fenomena tertentu. Melalui tersedianya persepsi lalu akan lahir sikap, yaitu suatu keinginan yang stabil untuk beraksi secara khusus didalam keadaan khusus pula. Pemahaman setiap orang akan berbeda tergantung aspek-aspek yang terdapat didalam pribadi perseorangan, serupa kepandaian seseorang, kapabilitas berfikir, konteks rujukan dan lain-lain. investigasi mengenai persepsi masyarakat ini sangat berguna lantaran dengan memahami persepsi tersebut akan membantu mencegah dampakdampak yang timbul.

\section{TELAAH LITERATUR}

\section{Konsep Persepsi}

Persepsi menurut kamus ilmiah merupakan penilikan, penggolongan stimulusstimulus dalam kesatuan-kesatuan, hal mengetahui, lewat indera, respons (indera) dan kapasitas menafsirkan. Menurut Sarlito dalam Rohmaul L \& Yudi Hartono (2015) persepsi secara umum yakni cara penerimaan, pemahaman, penetapan dan pengendalian informasi indrawi. Sedangkan menurut jalaluddin (2004:51) Persepsi ialah pengetahuan berkenaan dengan objek, kejadian, maupun kaitan-kaitan yang diperoleh dengan mengikhtisarkan informasi dan menerjemahkan pesan. Robins (2008:175) perception yakni metode dimana pribadi mengatur serta menginterpretasikan opni-opini sensorisnya guna menyampaikan arti bagi kalangan mereka. Jadi bisa diambil pendapat mengenai pengertian persepsi merupakan sebuah reaksi yang bermula dari rangsangan yang masuk ke indera-indera manusia yang kemudian diolah atau diintrepretasikan menjadi kesan-kesan baik itu kesan negatif maupun kesan positif.

\section{Masyarakat}

Masyarakat atau society berasal dari bahasa latin societas yang berarti hubungan persahabatan dengan yang lain. Societas diturunkan dari kata socius yang berarti teman, sehingga arti society berhubungan erat dengan kata sosial. Secara implisit, kata society mengandung makna bahwa setiap anggotanya mempunyai perhatian dan kepentingan sama dalam mencapai tujuan bersama. Dalam bahasa inggris, kata masyarakat ditafsirkan menjadi dua tafsir, yaitu society dan community. Commonity berdasarkan Arthur Hillman (1951) dalam Basrowi (2014:37) adalah:

"A definition of community must be inclusive enough to take account, of the variety of both physical and social forms which community take". Dengan perkataan lain, masyarakat sebagai community cukup memperhitungkan dua variasi dari suatu yang berhubungan dengan 
kehidupan bersama (antar manusia) dan lingkungan alam. Jadi, ciri dari community ditekankan pada kehidupan bersama dengan bersandar pada lokasi dan derajat hubungan sosial atau sentimen. Dalam Basrowi (2014:37-38) community ini diartikan oleh Hasan Shadily (1983) sebagai paguyuban yang memperlihatkan rasa sentimen yang sama seperti terdapat dalam gemennshaft. Anggota-anggota mencari kepuasan bersumber pada adat kebiasaan dan sentimen (faktor primer), kemudian diikuti atau diperkuat oleh lokalitas (faktor sekunder).

\section{Pembangkit Listrik Tenaga Panas Bumi}

Pembangkit listrik tenaga panas bumi merupakan pembangkit listrik yang menjadikan panas bumi (geothermal) sebagai energi penggeraknya (Contessa dkk, 2009). Sistem panas bumi di indonesia umumnya merupakan sistem hidrothermal yang mempunyai temperatur tinggi $\left(>225^{\circ} \mathrm{C}\right)$, hanya beberapa diantaranya yang mempunyai temperatur sedang (150$225^{\circ} \mathrm{C}$ ). Pengetahuan dari lapangan-lapangan panas bumi yang telah dikembangkan di dunia maupun di indonesia menunjukkan bahwa sistem panas bumi bertemperatur tinggi dan sedang, sangat potensial bila diusahakan sebagai pembangkit listrik. Potensi sumberdaya geothermal indonesia sangat besar, yaitu sekitar $27500 \mathrm{MW}$, sekitar 30-40\% potensi panas bumi dunia.

\section{METODE PENELITIAN}

Dalam riset ini, metode penelitian yang peneliti gunakan adalah penelitian kuantitatif dengan metode deskriptif. Penelitian ini dilaksanakan di Kecamatan Pauh Duo Kabupaten Solok Selatan dengan subjek penelitiannya adalah masyarakat di kecamatan tersebut. Dalam penelitian ini variabelnya hanya satu atau tunggal yaitu persepsi masyarakat terdap pembangunan Pembangkit Listrik Tega Panas Bumi (PLTP), dengan indikator yaitu aspek sosial, ekonomi, lingkungan. Populasi yang digunakan pada penelitian ini adalah masyrakat Kecamatan Pauh Duo. Pengambilan sampel pada penelitian ini menggunakan teknik pengambilan sampel dengan cara Cluster Sampling (Area sampling). Total populasi dari kedua nagari tersebut 10527 orang. penentuan sampel mengemukakan rumus Menurut Slovin dalam Prasetyo dan Lina Miftahul Jannah, (2005:136).

\section{HASIL DAN PEMBAHASAN}

\section{Persepsi Masyarakat Terhadap Pembangunan PLTP Secara Sosial.}

Persepsi masyarakat terhadap pembangunan dilihat dari aspek sosial ini adalah melihat bagaimana pandangan masyarakat terhadap dampak yang ditimbulkan dari 
pembangunan itu secara sosial. Persepsi menurut Sarlito dalam Rohmatul listyana \& Yudi Hartono (2015) persepsi secara umum yakni cara penerimaan, pemahaman, penetapan dan pengendalian informasi indrawi. Sedangkan dampak sosial menurut fardani dalam Isna Fitria \& Ricka O (2016) dampak sosial merupakan suatu bentuk akibat atau pengaruh yang terjadi karena adanya sesuatu hal. Pengaruh yang dimaknai adalah efek yang berlaku pada masyarakat, baik karena suatu kejadian itu mempengaruhi masyarakat atau hal lainnya didalam masyarakat. Rekapitulasi indeks persepsi masyarakat mengenai pembangunan PLTP secra sosial/aspek sosial. Dapat kita ketahui pada tabel 1 dibawah ini.

Tabel 1. Indeks Persepsi Masyarakat Tentang Pembangunan PLTP dari Aspek Sosial

\begin{tabular}{|c|c|c|c|c|}
\hline No & Pertanyaan & $\begin{array}{c}\text { Rata-rata jawaban } \\
\text { responden }\end{array}$ & $\begin{array}{l}\text { Indeks } \\
\text { persepsi }\end{array}$ & Interpretasi \\
\hline 1 & $\begin{array}{l}\text { Bagaimana hubungan antara } \\
\text { masyarakat dengan } \\
\text { perusahaan }\end{array}$ & 2,7 & 67,5 & Cukup Baik \\
\hline 2 & $\begin{array}{l}\text { Bagaimana tingkat } \\
\text { kepercayaan masyarakat } \\
\text { terhadap tokoh masyarakat } \\
\text { tentang informasi yang } \\
\text { mereka sampaikan }\end{array}$ & 2,34 & 58,5 & Cukup Baik \\
\hline 3 & 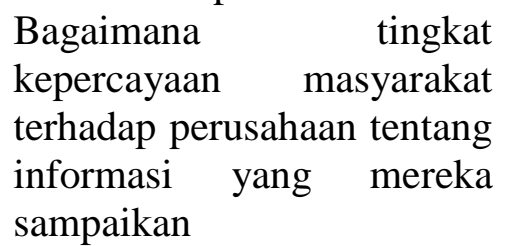 & 2,52 & 63 & Cukup Baik \\
\hline 4 & $\begin{array}{l}\text { Apakah pembangunan } \\
\text { PLTP mengganggu } \\
\text { kenyamanan masyarakat }\end{array}$ & 2,11 & 52,75 & $\begin{array}{l}\text { Kurang Baik } \\
\quad \text { (tidak } \\
\text { mengganggu) }\end{array}$ \\
\hline 5 & $\begin{array}{l}\text { Apakah masyarakat sering } \\
\text { protes terhadap perusahaan }\end{array}$ & 2,08 & 52 & Kurang Baik \\
\hline 6 & $\begin{array}{l}\text { Apakah } \\
\text { menanggapi } \\
\text { masyarakat }\end{array}$ & 2,17 & 54,25 & Kurang Baik \\
\hline 7 & $\begin{array}{l}\text { Apakah anda mendapatkan } \\
\text { informasi tentang } \\
\text { pembangunan PLTP }\end{array}$ & 2,01 & 50,25 & Kurang Baik \\
\hline & Jumlah & 2,27 & 56,89 & Cukup Baik \\
\hline
\end{tabular}

Berdasarkan tabel diatas, diperoleh gambaran mengenai persepsi masyarakat tentang pembangunan PLTP dilihat dari aspek sosial di Kecamatan Pauh Duo Kabupaten Solok Selatan mendapatkan indeks persepsi yang sedang/cukup baik dengan persentase sebesar 56,89 persen. Sehingga dapat dikatakan persepsi masyarakat atas pembangunan PLTP dilihat dari aspek sosial di Kecamatan Pauh Duo Kabupaten Solok Selatan sedang/cukup baik. 
Karena masyarakat berpersepsi bahwa hubungan masyarakat dengan perusahaan cukup baik, masyarakat juga cukup percaya terhadap informasi yang disampaikan oleh tokoh masyarakat ataupun perusahaan, masyarakat juga jarang melakukan protes terhadap perusahaan.

\section{Persepsi Masyarakat Terhadap Pembangunan PLTP Secara Ekonomi}

Persepsimmmmasyaraka terhadap pembangunanmdilihatttdari aspek ekonomi inixadalahhmelihat bagaimana pandangan masyarakat terhadap dampak yang ditimbulkan dari pembangunan itu secara ekonomi. Persepsi menurut Sarlito dalam Rohmatul listyana \& Yudi Hartono (2015) persepsi secara umum yakni cara penerimaan, pemahaman, penetapan dan pengendalian informasi indrawi. Sedangkan dampak ekonomi menurut Cohen dalam Isna Fitria \& Ricka O (2016) dampakkkekonomikkditafsirkan sebagai akibattdarixsuatu transisi yangxxterjadi di lingkungan.nApakah pembangunan merubah banyak terhadap kondisi ekonomi. Rekapitulasi indeks persepsi masyarakat tentang pembangunan PLTP dari aspek ekonomi. Bisa kita ketahui pada tabel 2 dibawah ini.

Tabel 2. Indeks Persepsi Masyarakat terhadap Pembangunan PLTP Secara Ekonomi

\begin{tabular}{|c|c|c|c|c|}
\hline No & Pertanyaan & $\begin{array}{l}\text { Rata-rata } \\
\text { jwaban } \\
\text { responden }\end{array}$ & $\begin{array}{c}\text { Indeks } \\
\text { persepsi }\end{array}$ & $\begin{array}{c}\text { Interpre } \\
\text { tasi }\end{array}$ \\
\hline 1 & $\begin{array}{l}\text { Seberapa besar pengaruh } \\
\text { pembangunan } \\
\text { terhadap mata pencarian }\end{array}$ & 1,93 & 48,25 & $\begin{array}{c}\text { Kurang } \\
\text { Baik }\end{array}$ \\
\hline 2 & $\begin{array}{l}\text { Adakah pengaruh tingkat } \\
\text { pendapatan masyarakat } \\
\text { setempat dengan adanya } \\
\text { pembangunan PLTP }\end{array}$ & 2,41 & 60,25 & $\begin{array}{c}\text { Cukup } \\
\text { Baik }\end{array}$ \\
\hline 3 & $\begin{array}{l}\text { Seberapa besar pengaruh } \\
\text { pembangunan } \\
\text { terhadap penurunan tingkat } \\
\text { pengangguran }\end{array}$ & 2,66 & 66,5 & $\begin{array}{c}\text { Cukup } \\
\text { Baik }\end{array}$ \\
\hline 4 & $\begin{array}{l}\text { Apakah pembangunan PLTP } \\
\text { menyebabkan harga tanah } \\
\text { naik disekitar proyek } \\
\text { pembangunan }\end{array}$ & 3,24 & 81 & Baik \\
\hline 5 & $\begin{array}{l}\text { Apakah pembangunan PLTP } \\
\text { berpengaruh terhadap } \\
\text { produktivitas pertanian }\end{array}$ & 1,83 & 45,75 & $\begin{array}{c}\text { Kurang } \\
\text { Baik }\end{array}$ \\
\hline & Jumlah & 2,41 & 60,35 & $\begin{array}{l}\text { Cukup } \\
\text { Baik }\end{array}$ \\
\hline
\end{tabular}

Berdasarkan tabel diatas, diperoleh gambaran mengenai persepsi masyarakat terhadap pembangunan PLTP dilihat dari aspek ekonomi di Kecamatan Pauh Duo Kabupaten Solok 
Selatan memiliki indeks persepsi yang sedang/cukup baik dengan persentase sebesar 60,35 persen. Sehingga dapat dikatakan persepsi masyarakat terhadap pembangunan PLTP dilihat dari aspek ekonomi di Kecamatan Pauh Duo Kabupaten Solok Selatan sedang/cukup baik. Karena dengan adanya pembangunan PLTP ini berpengaruh terhadap tingkat pendapatan masyarakat menjadi lebih baik, juga perpengaruh terhadap penurunan tingkat pengangguran karena pembangunan PLTP membutuhkan banyak tenaga kerja, dan menyebabkan harga tanah disekitar proyek pembangunan menjadi meningkat. Walaupun secara keseluruhan indeks persepsi masyarakat cukup baik, namun pembangunan PLTP ini berpengaruh kurang baik terhadap produktivitas pertanian.

\section{Persepsi Masyarakat Terhadap Pembangunan PLTP Secara Lingkungan.}

Persepsinnmasyarakat terhadap pembangunanmmdilihatxxdari aspek lingkungan ini adalah melihat bagaimana pandangan masyarakat terhadap dampak yang ditimbulkan dari pembangunan itu secara lingkungan. Persepsi menurut Sarlito dalam Rohmatul listyana \& Yudi Hartono (2015) persepsi secara umum yakni cara penerimaan, pemahaman, penetapan dan pengendalian informasi indrawi. Masalah lingkungan disini dipersepsikan ibarat ketimpangan diantara realitannnndannnnharapan-harapan kita semestinya.mDenganddemikian masalah lingkungannnnadalah kondisi-kondisi lingkungannnbiofisikkkkkyang merintangi kepuasanndanmkebutuhannmanusia untuk kesehatanndannkebahagiaan (Swan \& Staap dalam Hilmi Yusuf 2003). Rekapitulasi indeks persepsi masyarakat terhadap pembangunan PLTP secara lingkungan/aspek lingkungan. bisa dilihat pada tabel 3 dibawah ini.

Tabel 3. Indeks Persepsi Masyarakat Terhadap Pembangunan PLTP Secara lingkungan.

\begin{tabular}{llccc}
\hline No & \multicolumn{1}{c}{ Pertanyaan } & $\begin{array}{c}\text { Rata-rata } \\
\text { jwaban } \\
\text { responden }\end{array}$ & $\begin{array}{c}\text { Indeks } \\
\text { persepsi }\end{array}$ & $\begin{array}{c}\text { Interpre } \\
\text { tasi }\end{array}$ \\
\hline 1 & $\begin{array}{l}\text { Apakah setelah } \\
\text { pembangunan PLTP sering } \\
\text { terjadi kekeringan } \\
\text { Apakah } \\
\text { pembangunan PLTP terjadi } \\
\text { pencemaran sungai }\end{array}$ & 2,41 & 60,25 & $\begin{array}{c}\text { Cukup } \\
\text { Baik }\end{array}$ \\
3 & $\begin{array}{l}\text { Apakah } \\
\text { pembangunan PLTP terjadi } \\
\text { penurunan debit air sungai } \\
\text { Apakah } \\
\text { pembangunan PLTP terjadi } \\
\text { pencemaran udara }\end{array}$ & 3,04 & 76 & Baik \\
& 3,15 & 75,75 & Cukup \\
Baik
\end{tabular}




\begin{tabular}{clccc}
5 & $\begin{array}{l}\text { Apakah } \\
\text { pembangunan PLTP terjadi } \\
\text { amblesan tanah. }\end{array}$ & 3,56 & 89 & Baik \\
$6 \begin{array}{l}\text { Apakah pembangunan PLTP } \\
\text { berdampak kepada } \\
\text { kesuburan tanah }\end{array}$ & 3,12 & 78 & Baik \\
\hline & 3,05 & 76,29 & Baik \\
\hline
\end{tabular}

Berdasarkan tabel 3 diatas, diperoleh gambaran mengenai persepsi masyarakat terhadap pembangunan PLTP dilihat dari aspek lingkungan di Kecamatan Pauh Duo Kabupaten Solok Selatan memiliki indeks persepsi yang tinggi/baik dengan persentase sebesar 76,29 persen. Sehingga dapat dikatakan persepsi masyarakat mengenai pembangunan PLTP dilihat dari aspek lingkungan di Kecamatan Pauh Duo Kabupaten Solok Selatan tinggi/ baik. Persepsi tinggi/baik ini muncul karena menurut masyarakat, pembangunan PLTP ini tidak begitu berdampak terhadap lingkungan di sekitarnya. Kalaupun ada dampaknya, dampaknya itu hanya sedikit saja seperti pencemaran air hanya sedikit, hanya terjadi sedikit penurunan debit air sungai, dan tidak ada terjadi pencemaran udara akibat pembangunan PLTP ini.

\section{SIMPULAN DAN SARAN}

\section{Simpulan}

Berdasarkan hasil penelitian dan pembahasan yang telah dilakukan mengenai persepsi masyarakat terhadap pembangunan PLTP di kecamatan pauh duo kabupaten solok selatan, maka dapat ditarik kesimpulan bahwa:

1. Persepsi masyarakat terhadap pembangunan PLTP dilihat dari aspek sosial termasuk dalam kategori cukup baik yaitu sebesar 56,89. Skor persepsi ini menunjukkan secara sosial tidak ada permasalahan antara masyarakat dengan perusahaan yang ditandai dengan tidak adanya konflik yang terjadi antara masyarakat dengan perusahaan.

2. Persepsi masyarakat mengenai pembangunan PLTP dilihat dari aspek ekonomi termasuk dalam kategori cukup baik yaitu sebesar 60,35. Skor persepsi ini menunjukkan pembangunan PLTP ini memiliki dampak yang positif terhadap kondisi ekonomi masyarakat setempat. Terlihat dari penurunan tingkat pengangguran, bertambahnya tingkat pendapatan masyarakat, dan bertambahnya jumlah sarana ekonomi seperti warung makan sehingga perekonomian masyarakat lebih meningkat. 
3. Persepsi masyarakat terhadap pembangunan PLTP dilihat dari aspek lingkungan termasuk dalam kategori baik yaitu sebesar 76,29. Skor persepsi ini menunjukkan bahwa pembangkit listrik tenaga panas bumi ini merupakan pembangkit listrik yang ramah lingkungan.

\section{Saran}

Berdasarkan hasil penelitian dan pembahasan maka penulis dapat memberikan saran sebagai berikut :

1. Kepada pemerintah maupun PT Supreme Energi diharapkan untuk memberikan sosialisasi kepada masyarakat mengenai pembangunan PLTP ini, karena masyarakat masih banyak yang belum tahu apa itu pembangkit listrik tenaga panas bumi ini. Bahkan masyarakat juga tidak tau bahwa energi panas bumi ini merupakan energi yang terbarukan.

2. Masyarakat sekitar area pembangunan selaku pihak yang terdampak langsung dari pembangunan tersebut diharapkan untuk mapu berfikir secara kritis dan bijaksana.

\section{DAFTAR PUSTAKA}

Bambang prastyo dan lina miftahul jannah. 2005. Metode Penelitian Kuantitatif Teori Dan Aplikasi. Jakarta : Raja Grafindo Persada.

Basrowi. 2014. Pengantar Sosiologi. Bogor: Ghalia Indonesia.

Contessa dkk. 2009. Saluran Udara Tegangan Ekstra Tinggi : Pengaruhnya Pada Kesehatan Lingkungan.

Isna Fitria Agustina dan Ricka Octaviani. 2016. Analisis Dampak Sosial Dan Ekonomi Kebijakan Pengembangan Kawasan Mix Use Di Kecamatan Jabon. JKMP (ISSN. 2338-445X dan E-ISSN. 2527 9246), Vol. 4, No. 2.

Rahmat, Jalaluddin. 2005. Psikologi komunikasi. Bandung : PT Remaja Rosdakarya.

Robins. 2008. Perilaku Organisasi. Jakarta: Salemba Empat.

Rohmaul Listyana \& Yudi Hartono. 2015. Persepsi Dan Sikap Masyarakat Terhadap Penanggalan Jawa Dalam Penentuan Waktu Pernikahan (Studi Kasus Desa Jonggrang Kecamatan Barat Kabupaten Magetan Tahun 2013. Jurnal Agastya VOL $5 N O 1$. 